\title{
A note on the Australian freshwater crocodiles inhabiting Tunnel Creek cave, West Kimberley
}

\author{
Ruchira Somaweera', David Woods ${ }^{2}$ and Tracy Sonneman ${ }^{2}$ \\ ${ }^{1}$ Biologic Environmental Survey, 50B Angove Street, North Perth, Western Australia 6006, Australia. \\ ${ }^{2}$ Western Australian Department of Parks and Wildlife, West Kimberley District Office, \\ PO Box 65, Broome, Western Australia 6725, Australia.
}

KEYWORDS: Crocodylus johnstoni, hot water springs, thermochron iButtons, subterranean habitats

\begin{abstract}
INTRODUCTION
Tunnel Creek National Park, located $390 \mathrm{~km}$ east of Broome in the Kimberley region of Western Australia, is one of region's top tourist attractions. The 91 ha national park is positioned within the Napier Range which is composed of limestone, remnants of a Devonian barrier reef system formed around 350 million years ago (Goudie et al. 1990). The park contains a limestone cave system $\sim 750 \mathrm{~m}$ in length (cave entrance at $51 \mathrm{~K}$ 727683 8051871) (Figure 1). It is considered to be one of the oldest cave systems in Western Australia and also a nationally important wetland (Environment Australia 2001). The cave also has historical value as the Aboriginal freedom fighter Jandamarra, a member of the Bunuba group of the area, evaded the police and others for nearly three years using it as a hideout, until he was shot in April 1897 at the cave entrance (Pedersen and Woorunmurra 1995).
\end{abstract}

The cave is up to $20 \mathrm{~m}$ high and up to $20 \mathrm{~m}$ wide and contains permanent pools of freshwater throughout the year. Tunnel Creek generally flows during 4-5 months of the year (December to April), during which it is connected to a permanent, large freshwater pool located, $\sim 15 \mathrm{~m}$ outside the southern entrance of the cave (Figures 1, 2A). Nearly halfway in, the roof of the cave has collapsed allowing sunlight to reach the banks of the cave in a $\sim 30 \mathrm{~m}$ section. Other than this, sunlight does not penetrate the remainder of the cave, beyond the entrances. Two springs with warmer water, possibly created as a result of a perched water table passing through heated rocks outside the cave, flows into the cave creating $\sim 1 \mathrm{~m}$ and $\sim 2 \mathrm{~m}$ high waterfalls (Figure 1). Water within these two pools is warmer than the other pools within the cave.

While no detailed studies on the herpetofauna of the area have yet taken place, anecdotal information states the occasional presence of Australian freshwater crocodiles (Crocodylus johnstoni) inside the cave (Gueho 2003; Laurie 2010). Confirmed records of crocodilians inhabiting large caves are very rare and limited to a population each of the dwarf crocodile (Osteolaemus sp.) and the Nile crocodile (C. niloticus) (Handwerk 2003; IRD 2012). Hence in this short note, we provide more robust observational records of the population of $C$. johnstoni inhabiting the Tunnel Creek cave and discuss likely reasons for their occupation of the cave.

\section{METHODS}

During ongoing surveys by the Department of Parks and Wildlife of Western Australia for freshwater crocodiles in the West Kimberley region, Tunnel Creek cave was visited on eight occasions between May 2011 and September 2013 (Table 1). Spotlighting was conducted using headlamps and hand-held spotlights inside the cave (during daylight hours) and at the pool outside during night time (18:00-6:00). The outside pool was also searched for crocodiles and their signs more regularly during daytime. Once an eye shine was observed, attempts were made to approach the crocodile and estimate the size. Notes on the location and activity were made. On 9 June 2013, thermochron iButton data loggers [programmed to record temperature and relative humidity (in only those that were above water) at $20 \mathrm{~min}$ intervals over $17 \mathrm{hrs}$ ] were placed one per pool, $\sim 20 \mathrm{~cm}$ underwater near the waterfall inflows at the two warm pools, two other pools inside the cave (cold pools 2 and 4 ), and the pool outside, while two loggers each were placed $\sim 50 \mathrm{~cm}$ above ground level inside the cave (on ledges on the cave wall $\sim 200 \mathrm{~m}$ from an entrance) and outside (suspended in air from trees $\sim 50 \mathrm{~m}$ away from the two entrances). Those set above ground recorded both temperature and humidity. Additionally the air temperature was measured using a digital thermometer (CEM 4 in 1 Environment Meter DT-8820) outside the southern entrance and at the second warm pool inside the cave during visits (Table 1). 
TABLE 1 Observations of crocodiles made within the Tunnel Creek cave. Temperatures refer to those measured using a hand-held thermometer at the outside pool and the second warm pool inside the cave.

\begin{tabular}{|c|c|c|c|c|c|}
\hline Date & Time & $\begin{array}{l}\text { Outside air } \\
\text { temperature }\end{array}$ & $\begin{array}{l}\text { Inside air } \\
\text { temperature }\end{array}$ & $\begin{array}{l}\text { Number of } \\
\text { crocodiles }\end{array}$ & Observations \\
\hline 13 May 2011 & $11: 30$ & 24.7 & 21.6 & 2 & $\begin{array}{l}\text { 1. } 120-150 \mathrm{~cm} \text { animal on rocks directly under flowing } \\
\text { spring in warm pool } 1 \\
\text { 2. Eye shine in deep water at a cold pool } 2\end{array}$ \\
\hline 14 May 2011 & $19: 40$ & 16.9 & 19.3 & 2 & $\begin{array}{l}\text { 1. Eye shine at water's edge in warm pool } 1 \\
\text { 2. Eye shine in deep water at warm pool } 2\end{array}$ \\
\hline 2 Sep 2011 & $8: 10$ & 24.3 & 20.1 & 3 & $\begin{array}{l}\text { 1. } 150-180 \mathrm{~cm} \text { animal at water's edge in cold pool } 2 \\
\text { 2. Eye shine in deep water at warm pool } 1 \\
\text { 3. Eye shine in deep water at warm pool } 2\end{array}$ \\
\hline 16 June 2012 & $13: 20$ & 31.7 & 21.9 & 4 & $\begin{array}{l}\text { 1. } 150-180 \mathrm{~cm} \text { at water's edge in warm pool } 1 \\
\text { 2. } 120-150 \mathrm{~cm} \text { in deep water at warm pool } 2 \\
\text { 3. Eye shine in deep water at cold pool } 4 \\
\text { 4. Yearling }(37 \mathrm{~cm}) \text { in shallow cold pool, } \sim 60 \mathrm{~m} \text { inside } \\
\text { of the south entrance }\end{array}$ \\
\hline 16 June 2012 & $21: 20$ & 18.4 & 19.7 & 4 & $\begin{array}{l}\text { 1. } 150-180 \mathrm{~cm} \text { at water's edge in warm pool } 1 \\
\text { 2. } 120-150 \mathrm{~cm} \text { in deep water at warm pool } 2 \\
\text { 3. Two eye shines in deep water at cold pool } 4\end{array}$ \\
\hline 9 June 2013 & $8: 00$ & 27.6 & 23.4 & 2 & $\begin{array}{l}\text { 1. } 120-150 \mathrm{~cm} \text { animal on a rock directly under the } \\
\text { flowing spring at warm pool } 2 \\
\text { 2. Eye shine in deep water at cold pool } 2\end{array}$ \\
\hline 10 June 2013 & $6: 00$ & 22.6 & 23.0 & 3 & $\begin{array}{l}\text { 1. } 120-150 \mathrm{~cm} \text { on a sand bank bordering warm pool } 2 \\
\text { 2. } 120-150 \mathrm{~cm} \text { at water's edge in warm pool } 2 \\
\text { 3. Eye shine in deep water at cold pool } 4\end{array}$ \\
\hline 26 Sep 2013 & $8: 00$ & 21.6 & & 2 & $\begin{array}{l}\text { 1. } 150-180 \mathrm{~cm} \text { animal in shallow water directly under } \\
\text { flowing springs in warm pool } 1 \\
\text { 2. Eye shine in deep water at cold pool } 1\end{array}$ \\
\hline
\end{tabular}

\section{RESULTS}

At least two crocodiles were observed within the cave during each survey with four individuals observed in June 2012 (Table 1). Six of the 11 observations were made at less than $5 \mathrm{~m}$ from the animal and all individuals observed closely were noticeably paler in colour relative to those observed at Windjana Gorge, $\sim 30 \mathrm{~km}$ north-east, the closest other water body where surveys took place. Six observations were made at warm pool 1 and seven at warm pool 2, compared to nine observations in all other locations inside the cave, indicating a possible preference to warm pools (e.g. Figure 2B). The smallest individual encountered was a $37 \mathrm{~cm}$ (total length) hatchling in June 2012, which was estimated to be 7-8 months old. The largest, a 150-180 cm individual, was observed during four of the visits. Apart from one observation of a 120-150 $\mathrm{cm}$ crocodile on a sand bank (Figure 2C), all other observations were of animals in water. Numerous tracks were observed on the sand banks within the cave and those that lead to the pool outside (Figure 2D). Despite clear signs of crocodiles moving between the pools inside and outside, no crocodiles were observed in the outside pool during any of the surveys. The two warm springs inside the cave were flowing during all surveys except in September 2011 and September 2013, during the peak dry season. Tracks leading to the bank in the section where the roof has collapsed were observed in September 2013.

Data logger recordings on 9-10 June 2013 showed that the warmer pools maintained a temperature $\sim 0.5^{\circ}$ higher than the cold pools inside and were much more stable over the day (Figure 3). Contrastingly, the pool outside was cooler than the pools inside and the temperature gradually dropped through the night till the morning (being $\sim 1^{\circ}$ cooler than the warm pools at 13:20 to $\sim 1.5^{\circ}$ at $6: 20$ ). However it is noteworthy that these differences are small and within the error margins for iButtons. The air temperature inside the cave showed lower variation $\left(4.1^{\circ} \mathrm{C}\right.$, ranging from $\left.19.3-23.4^{\circ} \mathrm{C}\right)$ during the visits compared to $24.7^{\circ} \mathrm{C}$ (ranging from $16.9-41.6^{\circ} \mathrm{C}$ ), $\sim 50 \mathrm{~m}$ away but outside the cave (Table 1). Recordings from the data loggers show that the air temperature inside the cave remained largely stable for the 17 hour period on 9 June 2013 while the temperature outside dropped over the same time period (Figure 4). The Relative Humidity (RH) outside on the other hand, remained $20 \%$ less than that inside throughout the $17 \mathrm{hr}$ time period (Figure 4). 


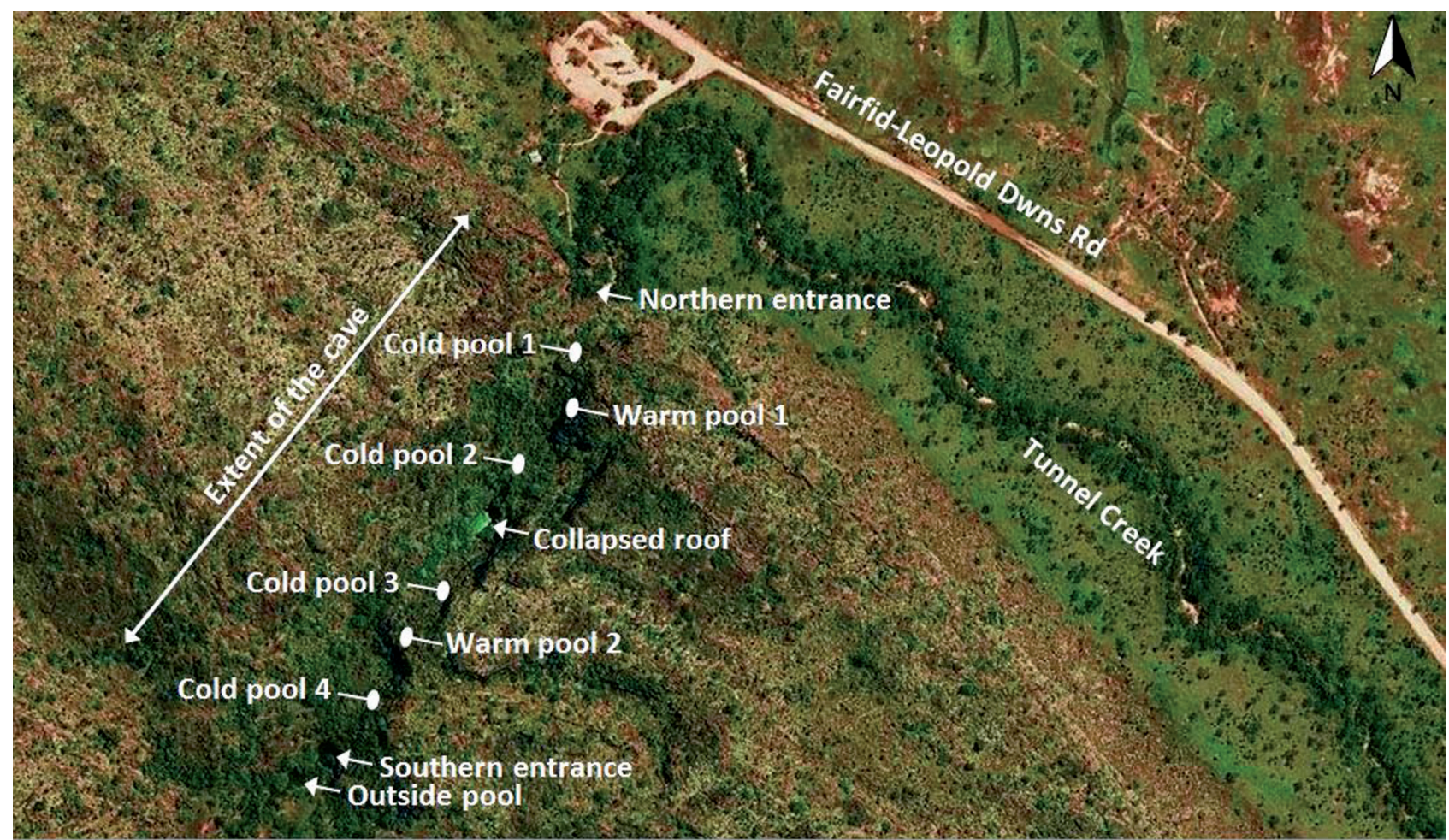

FIGURE 1 Relative positioning of the pools inside and outside the Tunnel Creek cave.

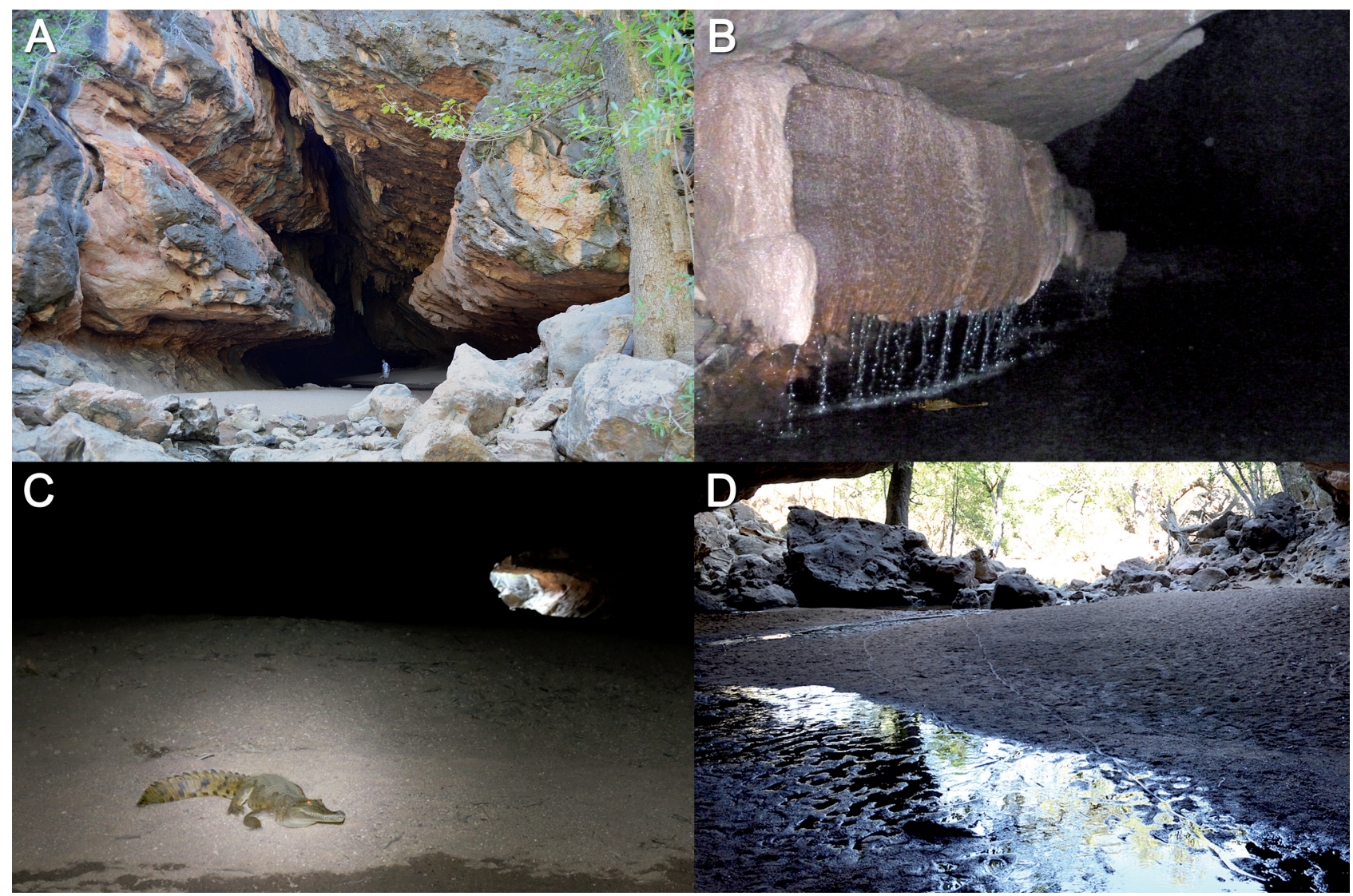

FIGURE 2 A, southern entrance of the Tunnel Creek cave; B, 120-150 cm crocodile directly under the spring at warm pool 2; C, 120-150 cm crocodile on sand bank inside the cave with the southern entrance in the background; D, tracks heading in and out of the cave. Photos A \& D: Karen Bettink; B \& C: Ruchira Somaweera. 


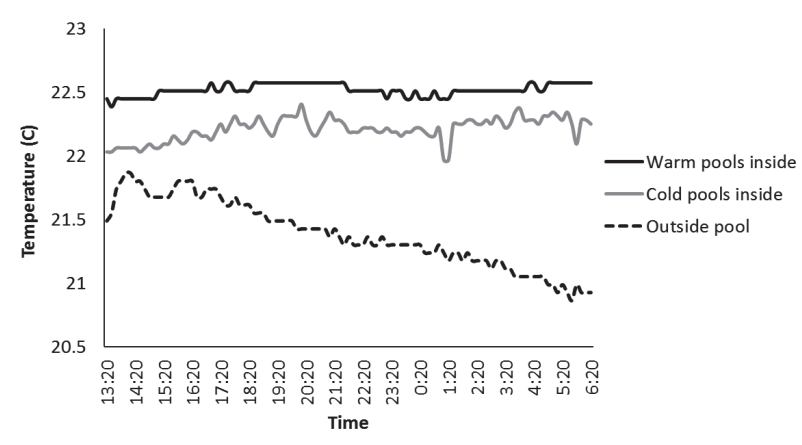

FIGURE 3 Comparison of mean water temperature of the two warm pools and two of the cold pools ( 2 and 4 ) inside the cave and the pool outside over 17 hrs on 9-10 June 2013.

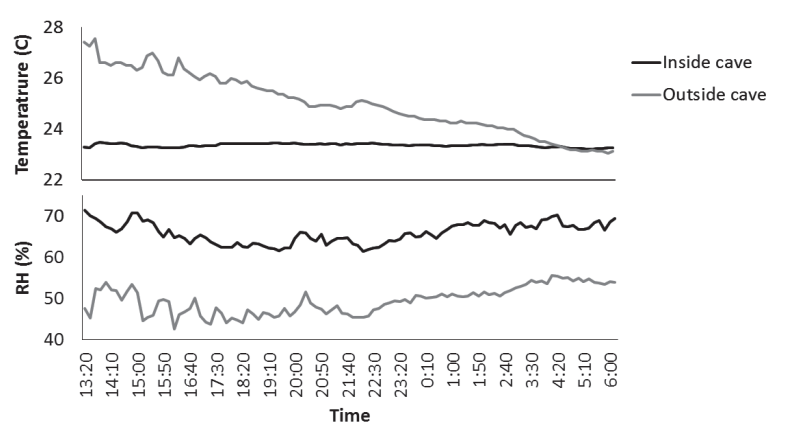

FIGURE 4 Comparison of mean air temperature (upper panel) and mean relative humidity (lower panel) inside and outside the cave over $17 \mathrm{hrs}$ on 9-10 June 2013.

\section{DISCUSSION}

Among the few known examples of crocodilians inhabiting large caves is a population of dwarf crocodiles (Osteolaemus sp.) in karst caves of Abanda in Gabon (IRD 2012). This unique population is morphologically different, live in complete darkness, and depend on a diet of cave dwelling animals including bats and invertebrates. A population of Nile crocodiles (C. niloticus) is known to inhabit the labyrinth of caves beneath Madagascar's Ankarana Nature Reserve (Handwerk 2003). Steubing et al. (2004) found tracks of false gharials (Tomistoma schlegelii) entering caves in Bukit Sarang in Sarawak, Malaysia but no direct observations of individuals were made.

Nevertheless, use of smaller subterranean habitats by crocodilians is well documented. Caverns or burrows are often used by smaller crocodilians as hideouts during daytime (e.g. Chinese alligator, Alligator sinensis, African dwarf crocodile, Ostolaemus tetraspis, smooth-fronted caiman Paleosuchus trigonatus:
Magnusson and Lima 1991; Brazaitis and Watanabe 2011); as refugia during the periods guarding nests and protecting hatchlings (e.g. mugger crocodile $C$. palustris, American crocodile C. acutus: Gupta and Bhardwaj 1995; Wasilewski and Enloe 2006); and also to avoid adverse environmental conditions such as drought and winter (e.g. Nile crocodile C. niloticus, American alligator Alligator mississippiensis: Cott 1961; Neill 1971). However, these burrows and tunnels are usually dug by the adults of the species, and in most instances are only used seasonally or as a hideout during part of the day.

Crocodylus johnstoni is endemic to mainland northern Australia and is widespread in the Kimberley region (Burbidge 1987), generally inhabiting upstream permanent freshwater habitats, although they may extends into tidal, brackish waters in a few river systems (Webb and Manolis 2010). Despite its wide range and occupation of a variety of aquatic habitats, there are no records of Australian freshwater crocodiles utilising subterranean habitats, other than using smaller caverns to aestivate during the dry season. Crocodylus johnstoni are known to seek refuge in subterranean shelters when water bodies dry entirely (Kennett and Christian 1993; Walsh 1989). Recaptures of C. johnstoni in the Northern Territory of Australia indicate high site fidelity to specific caverns for aestivation in the dry season. Potential advantages for $C$. johnstoni seeking shelter in caves to aestivate include predator avoidance, improved thermoregulation, and reduced rates of dehydration (Walsh 1989).

The occupation of Tunnel Creek cave by crocodiles may be based on thermal and foraging benefits. Observations show that crocodiles had a clear preference to warmer pools over cold pools. For example, the largest animal (150-180 cm) was always observed at a warm pool. Crocodilians, especially the dominant individuals, often seek the warmer water if available (Grigg and Seebacher 2001). In the dry season of September 2013, when one spring was not flowing, we observed clear signs of crocodiles coming up to the section with the collapsed roof, arguably for basking. However, it is likely that the crocodiles occupying the Tunnel Creek cave are mainly following a thermoconformity pattern where the body temperature equals water temperature (Seebacher and Grigg 1997), as the conditions inside the cave may not support active thermoregulation.

The cave may also provide foraging benefits for the crocodiles. Crocodylus johnstoni is an opportunistic predator having a wide breadth in prey items. Eel-tailed catfishes (Anodontiglanis dahli and Neosilurus hyrtlii), short-finned eels (Anguilla bicolor), spangled perch (Leiopotherapon unicolor) bony bream (Nematalosa erebi) and cherubin (Macrobrachium rosenbergii) are abundant in the much smaller pools within the cave (compared to the larger pool outside). Several species of bats (Macroderma gigas, Vespadelus caurinus, Vespadelus douglasorum, Miniopterus schreibersii, 
Pteropus scapulatus; see McKenzie and Bullen 2012 for additional species), frogs (e.g. Litoria caerulea, L. pallida) and snakes (e.g. Lialis olivaceus, Boiga irregularis) were observed within the cave during the surveys and all these groups are known prey items of freshwater crocodiles (Tucker et al. 1996; Webb et al. 1982). Predator avoidance may not be a potential reason for inhabiting the cave as most animals observed were adults or sub-adults, those without a natural predator in the area.

The much paler colouration observed in the crocodiles at Tunnel Creek cave could have mainly been a result of the darker conditions within the cave, as crocodilians in darker environments tends to develop lighter body colours (Richardson et al. 2002; but see Kirshner 1985). However, animals with high growth rates also tend to be paler than their counterparts that are subordinate, probably due to hormonal influence (Richardson et al. 2002; C. Manolis, pers. comm., 2013). It is also possible that the lighter colour was an artefact of agitation/excitement due to us approaching the crocodiles (Kirshner 1985), although we did not observe similar colour changes in other sites where crocodiles were caught by us. The Osteolaemus $s p$. in karst caves of Abanda in Gabon has a lighter and a more orange body colour compared to those outside (IRD 2012), but the C. niloticus individuals in the caves at Ankarana Nature Reserve are of normal pigmentation (Wilson 1987).

\section{ACKNOWLEDGMENTS}

We are grateful to the Bunaba rangers, Naomi Findlay, Andre Bobojcov, Ingrid Elmitt, Morgan O'Connell, Rachael Buzio, Francine James, Karen Bettink and Alison Russell for the support given during field surveys. Charlie Manolis, Gordon Grigg and two anonymous reviewers provided useful comments on this note.

\section{REFERENCES}

Brazaitis, P. and Watanabe, M.E. (2011). Crocodilian behaviour: a window to dinosaur behaviour? Historical Biology 23: 73-90.

Burbidge, A.A. (1987). The management of crocodiles in Western Australia. In: Webb, G.J.W., Manolis, S.C. and Whitehead, P.J. (eds), Wildlife Management: Crocodiles and Alligators: 125-127. (Surrey Beatty: Sydney).

Cott, H. (1961). Scientific results of an inquiry into the ecology and economic status of the Nile crocodile (Crocodylus niloticus) in Uganda and Northern Rhodesia. Transactions of the Zoological Society of London 29: 211-356.

Environment Australia (2001). A Directory of Important Wetlands in Australia, Third Edition. Environment Australia: Canberra.

Goudie, A., Viles, H., Allison, R., Day, M., Livingstone, I. and Bull, P. (1990). The geomorphology of the Napier Range, Western Australia. Transactions of the Institute of British Geographers 15: 308-322.

Grigg, G.C. and Seebacher, F. (2001). Crocodilian thermal relations. In: Grigg, G.C., Seebacher, F. and Franklin, C.E. (eds), Crocodilian Biology and Evolution: 297-309. Chipping Norton, N.S.W., Australia.

Gueho, R. (2003). Icons of Kimberley: An A to Z for Guides and Travellers. Northern Habitat: Australia.

Gupta, R.C. and Bhardwaj, C.S. (1995). Investigation on the tunnel ecology of Crocodylus palustris Lesson. Journal of Environmental Biology 16: 167-174.

Handwerk, B. (2003). Investigating africa's mysterious cave crocodiles $<$ http://news.nationalgeographic.com.au/ news/2003/06/0620_030620_cavecrocs.html>. National Geographic News. (Accessed on 26 September 2013.)

IRD (2012). The orange cave-dwelling crocodiles $<$ http://www. abanda-expedition.org/orange-cave-dwelling-crocodile-012. html >. (Accessed on 26 September 2013.)

Kennett, R. and Christian, K. (1993). Aestivation by freshwater crocodiles, Crocodylus johnstoni, occupying a seasonally ephemeral creek in tropical Australia. In: Lunney, D. and Ayers, D. (eds), Herpetology in Australia: 315-319. Surrey Beatty and Sons: Sydney.

Kirshner, D. (1985). Environmental effects on dorsal coloration in the saltwater crocodile, Crocodylus porosus. In: Grigg, G., Shine, R. and Ehmann, H. (eds), Biology of Australasian frogs and reptiles: 397-402. Surrey Beatty and Sons: Chipping Norton.

Laurie, V. (2010). The Kimberley: Australia's Last Great Wilderness. University of Western Australia Press: Nedlands.

Magnusson, W.E. and Lima, A.P. (1991). The ecology of a cryptic predator, Paleosuchus tigonatus, in a tropical rainforest. Journal of Herpetology 25: 41-48.

McKenzie, N.L. and Bullen, R.D. (2012). An acoustic survey of zoophagic bats on islands in the Kimberley, Western Australia, including data on the echolocation ecology, organisation and habitat relationships of regional communities. Records of the Western Australian Museum, Supplement 81: 67-108.

Neill, W.T. (1971). The Last of the Ruling Reptiles: Alligators, Crocodiles, and their Kin. Columbia University Press: New York.

Pedersen, H. and Woorunmurra, B. (1995). Jandamarra and the Bunuba resistance. (Magabala Books: Broome.)

Richardson, K.C., Webb, G.J.W. and Manolis, S.C. (2002). Crocodiles Inside Out: a Guide to the Crocodilians and their Functional Morphology. Surrey Beatty \& Sons: Chipping Norton.

Seebacher, F. and Grigg, G.C. (1997). Patterns of body temperature in wild freshwater crocodiles, Crocodylus johnstoni: thermoregulation versus thermoconformity, seasonal acclimatization, and the effect of social interactions. Copeia 1997: 549-557.

Steubing, R.B., Lim, C.K. and Bezuijen, M. (2004). Use of caves by Tomistoma schlegelii in Sarawak, Malaysia. Crocodile Specialist Group Newsletter 23: 11-12.

Tucker, A.D., Limpus, C.J., McCallum, H.I. and McDonald, K.R. (1996). Ontogenetic dietary partitioning by Crocodylus johnstoni during the dry season. Copeia 1996: 978-988.

Walsh, B. (1989). Aestivation in the Australian freshwater crocodile? Australian Zoologist 25: 68-70. 
Wasilewski, J.A. and Enloe, B. (2006). The status of american crocodiles (Crocodylus acutus) at Turkey Point Nuclear Power Plant, Florida, USA. In: Crocodiles: Proceedings of the 18th Working Meeting of the Crocodile Specialist Group of the Species Survival Commission of IUCN - The World Conservation Union: 285-292. IUCN - The World Conservation Union, Gland, Switzerland and Cambridge United Kingdom.

Webb, G.J.W., Manolis, S.C. and Buckworth, R. (1982). Crocodylus johnstoni in the McKinlay River Area, N.T. I. Variation in the diet, and a new method of assessing the relative importance of prey. Australia Journal of Zoology 30: $877-899$.

Webb, G.J.W. and Manolis, S.C. (2010). Australian freshwater crocodile Crocodylus johnstoni. In: Manolis, S.C. and Stevenson, C. (eds), Crocodiles. Status Survey and Conservation Action Plan: 66-70. Crocodile Specialist Group: Darwin.

Wilson, J. (1987). The crocodile caves of Ankarana: expedition to northern Madagascar, 1986. Cave Science 14: 107-119.

MANUSCRIPT RECEIVED 30 OCTOBER 2013; ACCEPTED 5 APRIL 2014. 